\title{
ANALYSIS NEEDED FOR PREPARATION OF TEACHING MATERIALS IN ENGLISH FOR MEDICAL PERSONNEL IN BATAM CITY
}

\author{
Hendra Nugraha ${ }^{1}$ \\ Universitas Internasional Batam (UIB), Batam, Indonesia \\ nugraha@uib.ac.id ${ }^{1}$ \\ Chairunisa $^{2}$ \\ Universitas Internasional Batam (UIB), Batam, Indonesia \\ chairunisa@uib.ac.id ${ }^{2}$
}

\begin{abstract}
This study aims to find out the needs, functions, and problems faced by medical personnel in Batam city in using English for the medical field. Research is useful for developing language training and courses for special needs through analysis used to map the concrete needs of users. This research uses quantitative methods where the use of quantitative methods and data. Instruments and techniques of data collection is the way how the author uses strategies and instruments to collect data, in this case the authors collected data with questionnaires and asked respondents to fill it out and use the data processor. Based on the research results, it was found that the most needed English language skill was speaking. Therefore, the teaching materials that will be compiled are those that support speaking skills. As a learning direction, the teaching materials that are prepared also need to include elements of the function of English which are considered important for medical personnel in Batam City, namely to provide information. Finally, in compiling English teaching materials for medical personnel, it is necessary to include English grammar skills in order to support the confidence of medical personnel in Batam City.
\end{abstract}

Keywords: needs analysis, English, medical personnel

\section{INTRODUCTION}

This study aims to find out the needs, functions, and problems faced by medical personnel in using English for the medical field. Researchers chose medical personnel in Batam because Batam is the foremost area of Indonesia in the $3 \mathrm{~T}$ scheme (underdeveloped, foremost, and outermost) which requires significant development (DitjenPDT, 13/04/17). Bersebrangan with Singapore and Malaysia, Batam was one of the gates of Indonesia visited and traversed $m$ as yarakat world. 
Vol. 2 No. 2

December 2020

e- ISSN 2685 - 0559

p- ISSN $2684-673 X$

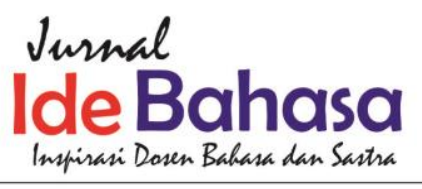

Researchers are interested in finding the needs, functions and problems faced by medical personnel in Batam city in facing global communication through English. By knowing the problems in using English as the language of global requirements, this study can be used as a suggestion for developing English language training through empowerment activities for medical personnel, especially in Batam.

With the entry into force of the ASEAN Economic Community (AEC) in 2015 , the public Indonesia is required to have foreign language skills, particularly English which is the language that is accepted internationally. Jones (2016) states that developed countries will develop efforts to open up new business opportunities. When viewed domestically, Indonesia is a country that has a large market potential and a very large population. However, what happened was that human resources were not ready for global competition. Thus, mastery of the English language is an opportunity to increase the competitiveness of Indonesian human resources.

Batam Island is included in the Riau Islands Province of Indonesia and has an independent administration, namely the Batam City Government (Pemko) and the Batam Concession Agency (BP). Batam t erletak in international waters importantly profitable in the Indian Ocean, the Atlantic Ocean and the Strait of Malacca. Batam is an island that is only within twenty kilometers from Singapore and the island of the most developed in the Riau Islands that make the border region of Indonesia. Batam has unique natural resources such as forests, coastal plains, and many beautiful coastal scenery. Until now, the

City of Batam being intensively developed a variety of industrial and commercial center and tourist destination both for tourists domesti $k$ and internationally .

As a step towards a tourist city, both the community and the Batam city government are promoting the opening and development of tourist areas in locations that have potential. For example, it is Rempang and Galang Island area which is connected to the Trans Barelang Bridge. Administratively, the two islands are still included in the Galang District of Batam City. In this area there is a very beautiful beach tourist location. The tourist area needs to be prepared for human resources in order to develop the economic capacity of the local community.

As a rapidly developing and strategic area, Batam needs to be prepared for the rapid change of international workers who are soon free to roam in Indonesia. Therefore, human resource development is a crucial issue in facing globalization and the AEC. There are several areas that must be addressed such as industry, business and tourism where Batam citizens can compete. To compete with foreigners, the minimum competency that must be maintained is the ability to speak English. For this problem, scholars have the responsibility to develop curricula and teaching materials are appropriate in a particular field or seb How can English to peruntuk $\mathrm{k}$ an $\mathrm{k}$ Husus or $\mathrm{d} i$ refer to as English for Specific Purpose (ESP) . However, as the basis for the curriculum and teaching materials, a needs analysis must be carried out to find the weakest points and significant problems (Astika, 2014) faced by Batam medical personnel in using English in the 
Vol. 2 No. 2

December 2020

e- ISSN 2685 - 0559

p- ISSN $2684-673 X$

tourism sector. Based on the explanation above, the author initiated a study entitled Compilation of English Teaching Materials Based on the Needs Analysis for Medical Personnel in Batam City .

This researcher aims to find the need for English skills of medical personnel in Batam city in communicating, especially with foreign patients . In addition, this study intends to find the function of Batam medical personnel's use of English in their work. Lastly, this study looks at problems faced by Batam medical personnel in their work.

This research covers medical personnel in Batam City. Specifically, this research will be conducted at Awal Bros Hospital and St. Hospital. Elizabeth - The research will be focused on medical personnel who manage or are involved in hospital management .

Theoretically, this study can provide evidence of the need for English skills for medical personnel in their work area . This evidence can later trace the need for further research in different locations, fields and workplaces. In practical terms, this research can guide curriculum and teaching methods for vocational schools, especially in English language training for employees.

\section{LITERATURE REVIEW}

Applied linguistics covers a wide field of study which may have intersections with other disciplines such as pedagogy, sociology, anthropology, etc. This study uses applied linguistics in terms of describing the need for English for medical personnel to develop vocational education or language training . Schimt (2010: 1) defines applied linguistics as:
In a broad sense, applied linguistics is concerned with increasing understanding of the role of language in human affairs and with providing the knowledge necessary for those who are responsible for taking languagerelated decisions whether the need for these arises in the classroom, the workplace, the law court, or the laboratory.

The language skills needed by medical personnel are basically a process of interaction between the interlocutors. Thus, this interaction involves language acquisition of a particular language. In Indonesia, English is not a second language but a foreign language because English is not used for personal or administrative domains. There are some areas such as Batam which are familiar with the Singaporean English variant due to its proximity to Singapore and Malaysia but Bahasa Indonesia is used for the same purpose.

Some companies and companies based internationally use English as a medium of communication such as conversations and administrative documentation. Thus, English language skills should be measured for those working in them with related English. Language acquisition for speakers of foreign languages is maintained not naturally developed through intense interaction but is often researched during language training or courses. The universal model for language training and courses is no longer relevant to the various fields of language used (Cohen, 2016). Therefore, there must be a special analysis of the language requirements for a particular field known as English for Specific Purposes. 
Vol. 2 No. 2

December 2020

e- ISSN 2685 - 0559

p- ISSN $2684-673 X$

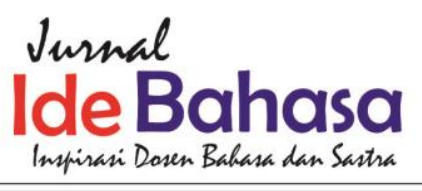

To develop such language training and courses, needs analysis is used to map the concrete needs of users.

A needs analysis is carried out to find a better formula for improving the training or course. It i ni may illustrate the point that significant further enhanced during the course and to improve the quality of human resources (Davies, 2007: 92). Curriculum designers and trainers are familiar with this kind of analysis. In linguistics, needs analysis is related to applied linguistics which examines the acceptance of language, especially second language (L2). However, there is some need analysis for English as a foreign language and researchers intend to fill this gap.

The result of this research is to develop a specific design of the specified language courses to meet the needs of different users. Mackay in Prachanant (2012) describes types of needs analysis, the first is academic and the second is task-based needs. Academic needs see the need for language acquisition for academic purposes while task-based needs require the language liberation needed to perform certain tasks.

There has been some research on the analysis of language needs for both academic and work-based purposes. The first research was conducted by Prachanant (2012). This study aims to determine the needs, functions, and problems of using English in the tourism industry. This research was conducted on 40 participants who work on Thai tourism sites.

The second research was conducted by Araminta (2015). This study primarily seeks the needs of English engineering students. The research is focused on three issues, namely analysis of the target situation, analysis of the current situation, and analysis of the teaching context.

\section{RESEARCH METHOD}

This chapter describes the research design, research variables / operating framework, population and sample, data collection instruments and techniques, data analysis, test design, location and time of study. Research methodology is a way to systematically solve research problems. This can be understood as the study of how research is conducted scientifically.

This research uses quantitative methods where the use of quantitative methods and data. Quantitative research is based on measuring quantities or quantities. This applies to phenomena that can be expressed in terms of the need for language skills for medical personnel, the functioning of English in tourism, and the problems encountered in using English to communicate. To collect the required data, questionnaires were distributed to medical personnel from several areas in Batam that have tourist areas and used English in communicating with foreign tourists. After being collected, the questionnaire was analyzed with the frequency of English skill needs, the function of English in work, and problems in using English.

The variables in this study are the need for English skills (X), the function of English in working jobs $(\mathrm{Y})$, and problems in using English (Z). Population and sample according to Prasetyo and Jannah (2011: 119) illustrates that the population is a symptom or unit to be studied, while the sample is part of the population to be studied. The population for the study 
were medical personnel in Batam City who worked at Awal Bros Hospital and St. Hospital. Elizabeth Batam City . These hospitals were chosen because they are the central tourist area of Batam City which is often visited by patients from outside Indonesia.

The sample in this study according to Prasetyo and Jannah (2011: 131) is purposive random sampling. This study took 100 participants as respondents. The respondent is the power of medical that pitch I ibat in the management of the hospital .

Instruments and techniques of data collection is the way how the author uses strategies and instruments to collect data, in this case the authors collected data by questionnaire and asked respondents to fill it out and use the data processor. But in the case of surveys, data can be collected in one or more of the following ways. The author collects data by giving respondents a questionnaire that involves part of the utterance and reading test. There are several ways of collecting appropriate data that differ widely in the context of the costs, time and other resources available to researchers.

The data collection instrument in this study was a questionnaire and a google sheet data processor from which the authors asked respondents to fill out a questionnaire consisting of these fields. This area is then transformed into questions in Indonesian to ensure respondents clearly understand the questions so that the answers they provide will be valid. The following is a grid of questions that will be given to respondents.

The $X$ variable, namely the Need for Language Skills, is divided into 4 points, namely Listening, Speaking, Reading,
Writing . For the function of English in work, it is stated as follows: General conversation, Providing information, Providing Services, Offering Assistance, Requesting Cooperation , Answering questions and solving problems

There are 26 questions that must be filled in by the respondent. The questionnaire is distributed through the WhatsApp application and respondents can fill it out online because it is written in google form. This method is efficient regarding advances in information technology and the popularity of the WhatsApp application.

After the data is collected, the writer will analyze it. Data analysis requires a number of closely related operations such as forming categories, applying these categories to raw data via coding, tabulating and then drawing statistical conclusions. Tabulation is a part of a technical procedure in which classified data is positioned in tabular form. Data tabulated by computer. Computers not only save time but also make it possible to study two variables that impinge on a problem simultaneously.

Based on the research objectives, the researcher will assess the frequency of English language skills most needed, the function of English use in industry per region, and finally, the problems most respondents encounter in using English.

\section{RESULT AND DISCUSSION}

The learning process is the process of gaining knowledge, practicing and being able to change behavior caused by learning experiences. Learning can be obtained from design or using certain teaching materials. This concept implies that if the design is right, the learning outcomes will be more optimal - Learning needs can come from the 
Vol. 2 No. 2

December 2020

e- ISSN 2685 - 0559

p- ISSN $2684-673 X$

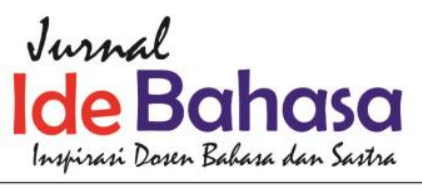

existence of someone's needs in their work. This need will be a driving force for people who will live in certain situations and conditions and continue to develop.

Maslow, a psychologist, implies that the basic human needs are divided from the lowest level to the highest level. This theory is called the "human needs" theory. Besides, the need for learning is defined as the gap in the current situation compared with the conditions that must be in a condition that is different, but identical. In other words, any situation less than that should indicate a "need", if the gap is large or has further consequences, should be considered a priority that needs to be addressed.

Learning needs vary widely. Such person has a need of different learning objective. Such learning needs, felt by someone in a rural area, may be different from the learning needs felt by people living in an urban area. The learning needs felt last year may be different from the learning needs felt next year. If the need for learning has been met, other learning needs will arise which must be met through learning activities, learning needs must be identified through an individual approach.

Based on the results of a survey conducted on 22 participants, speaking ability is the ability most needed by medical personnel in Batam City. Speaking is the ability to pronounce articulated sounds or words to express, express and convey thoughts, ideas and feelings. This understanding shows clearly that speaking is related to the pronunciation of words that aim to convey what will be conveyed, be it feelings, ideas or ideas. The ideas and ideas expressed are also related to the speaker's confidence, pronunciation and vocabulary.

The need for speaking in the medical field includes improving services in employment as medical personnel. This need can be a constant trend that exists in medical personnel who will be an impetus to achieve certain goals. It is important to identify learning needs as the basis for the preparation of a learning program. Where learning needs are identified, it will indicate where program activities are directed. Current learning needs are student competencies compared to student competencies that must be mastered. The gaps considered are gaps in knowledge, skills or relationships, and not other gaps that will be addressed in the learning process.

Regarding the function of English in the field of employment for medical personnel, providing information is the most widely recognized function. Seen from graph 4.2, providing information on work. It should be noted that the function of using English in the work of medical personnel is that all points have a slight difference, which is below 3.Thus, it appears that English is not widely used in the medical field in Batam City.

Planning for the implementation of learning needs, student involvement is very necessary, because the resources or potential of each student, and possible obstacles to learning will be displayed according to the group, which will then be carried out according to the learning needs of each group. Learning needs will be ordered carefully and consistently, after which priority needs for learning or basic interest and 
Vol. 2 No. 2

December 2020

e- ISSN 2685 - 0559

p- ISSN $2684-673 X$

freshness will be determined, which must be met through learning activities.

Regarding the problems in speaking English, the participants admitted that grammar is crucial. Speaking is the ability to pronounce articulated sounds or words to express, express and convey thoughts, ideas and feelings. This understanding clearly shows that speaking is related to the pronunciation of words that aim to convey what will be conveyed, be it feelings, ideas or ideas. The ideas and ideas expressed are also related to the speaker's confidence, pronunciation and vocabulary.

The highest reading problem is a vocabulary problem. The ability to read is the ability and skill and readiness of a person to understand the ideas and symbols or sounds of the language in a reading text that is adjusted to the reader's intent and purpose to get the message or information desired. Reading requires a good understanding, because reading requires good skills in order to understand the reading text and interpret the content well.

The highest problem in writing is English grammar. However, seen as a whole, it appears that every question asked gets a score that is not far off. Writing as for indirect communication with other people. Efforts to express everything that is contained in the concept of thought into written or written language. Therefore, writing is an activity that requires the ability to express opinions, ideas, ideas, and imagination in written language.

Most of the listening problems are foreign speakers speaking too fast. One of the obstacles that sometimes makes communication ineffective is a person's lack of listening skills. We may think of listening as something that requires no thought or effort. Success in communication is actually listening when the other person is talking. This will result in failure to absorb information and to respond accordingly.

\section{CONCLUSION}

Based on the research results, it was found that the most needed English language skill was speaking. Therefore, the teaching materials that will be compiled are those that support speaking skills. As a learning direction, the teaching materials that are prepared also need to include elements of the function of English which are considered important for medical personnel in Batam City, namely to provide information. Finally, in compiling English teaching materials for medical personnel, it is necessary to include English grammar skills in order to support the confidence of medical personnel in Batam City.

\section{REFERENCES}

Schmitt, Norbert (ed). 2010. An Introduction to Applied Linguistics. London: Routlegde.

Lynch, Tony dan David Mendhelson. 2010. Listening. In Schmitt, Norbert (ed). 2010. An Introduction to Applied Linguistics. London: Routlegde.

Burns, Anne dan Barbara Seidlhofer. 2010. Speaking and Pronunciation. In Schmitt, Norbert (ed). 2010. An Introduction to Applied Linguistics. London: Routlegde.

Carrel, Particia L dan William Grabe. 2010. Reading. Schmitt, Norbert (ed). 2010. An Introduction to Applied Linguistics. London: Routlegde. 
Vol. 2 No. 2

December 2020

e- ISSN 2685 - 0559

Matsuda, Paul Kei dan Tony Silva. 2010.

Writing. In Schmitt, Norbert (ed). 2010. An Introduction to Applied Linguistics. London: Routlegde.

Cuti, Astika. 2014. The Role of Need Analysis in English for Specific Purposes. Salatiga: Universitas Kristen Satya Wacana.
Prachanant. Nawamin. 2012. Needs Analysis on English Language Use in Tourism Industry. Procedia - Social and Behavioral Sciences 66 ( 2012 ) $117-125$ 